\title{
Bioinductive Collagen Implant Augmentation for the Repair of Chronic Lower Extremity Tendinopathies: A Report of Two Cases
}

\author{
Austin M. Looney ${ }^{1}$, Luc M. Fortier ${ }^{2}$, Joseph D. Leider ${ }^{2}$, Brandon J. Bryant ${ }^{3}$ \\ 1. Department of Orthopaedic Surgery, Georgetown University Medical Center, Washington, DC, USA 2. Department of \\ Orthopaedic Surgery, Georgetown University School of Medicine, Washington, DC, USA 3. Department of Orthopaedics, \\ Sports Medicine Division, Inova Fairfax Hospital, Falls Church, USA
}

Corresponding author: Luc M. Fortier, lucmfortier@gmail.com

\begin{abstract}
In this report, we present two cases of refractory chronic lower extremity tendinopathies treated with collagen bioinductive implant augmentation: a 20 -year-old male football player with chronic patellar tendinopathy and a 40-year-old active female with chronic proximal hamstring tendinopathy. We demonstrate that bioaugmentation may represent an effective strategy in the surgical treatment of chronic tendinopathies. Both patients were able to return to their pre-injury activity levels at an accelerated rate.
\end{abstract}

Review began 05/24/2021 Review ended 05/31/2021 Published 06/10/2021

๑) Copyright 2021 Looney et al. This is an open access article distributed under the terms of the Creative Commons Attribution License CC-BY 4.0., which permits unrestricted use, distribution, and reproduction in any medium, provided the original author and source are credited.
Categories: Orthopedics, Healthcare Technology, Other

Keywords: chronic tendinopathy, bioinductive augmentation, sports medicine, bioinductive implant, hamstring tendon, regeneten, patellar tendinopathy, hamstring surgery, bioinduction

\section{Introduction}

Chronic tendinopathies can be difficult to treat. Patellar tendinopathy is most commonly reported in athletes who play sports that involve strenuous jumping, particularly elite-level volleyball players [1]. Proximal hamstring tendinopathies occur more frequently in runners and soccer players [2-3]. In both cases, a trial of conservative treatment is warranted, consisting of activity modification, nonsteroidal antiinflammatory drugs (NSAIDs), and physiotherapy [4-5]. While nonoperative strategies may be successful in a majority of cases, approximately $25-30 \%$ of patients are unable to return to their sport with conservative measures alone and may benefit from surgical debridement and repair [6-7]. The use of bioinductive implants has emerged as a promising option in orthopedic surgery to facilitate healing and enhance the strength of tissue repair [8]. These implants act as an artificial structure capable of supporting threedimensional tissue formation that allows for cell attachment and migration, delivery of biochemical factors, and diffusion of cell nutrients to improve the local tissue environment and promote healing [8-9]. The implants are minimally cross-linked and freeze-dried and are designed to gradually undergo degradation within six months, leaving a layer of new tendon-like tissue; this new tissue decreases peak strain, thereby creating an environment conducive to healing [10].

Regeneten (Smith \& Nephew, Inc., Andover, MA) is a bioinductive implant composed of type 1 collagen derived from bovine Achilles tendon, which acts as a highly porous scaffold allowing the attachment of regenerative cells and transport of nutrients and waste. While initial results of Regeneten augmentation of rotator cuff repairs have been promising [11], its utility outside of the shoulder is not well explored. limited to a single case report involving bioaugmentation of surgically managed chronic patellar tendinopathy and technique descriptions without follow-up for hip abductor repairs [12-14]. As with any implant, there is a theoretical risk of an inflammatory or foreign body reaction. However, these risks have not been proven to be an issue in the literature [15-16].

We present two cases where the Regeneten bioinductive implant was utilized for the bioaugmentation of repairs of the refractory chronic patellar tendon and proximal hamstring tendinopathies. Verbal and written consent was obtained from the patients for the publication of this article.

\section{Case Presentation}

\section{Patient 1: chronic patellar tendinopathy}

A 20-year-old male collegiate football athlete presented with 14 months of atraumatic right knee pain localized to the patellar tendon. His symptoms were exacerbated by activity and had progressed to the point where he was no longer able to play. He denied associated swelling, stiffness, or mechanical symptoms. Examination revealed normal alignment, no effusion, no joint line tenderness, and stable ligaments, with tenderness just distal to the inferior patellar pole. After 11 months of activity modification and conservative treatment failed to alleviate the pain, an MRI of the right knee was performed, which revealed patellar tendinosis with a high-grade partial proximal tear (Figure 1), and the patient elected to undergo 


\section{Cureus}

debridement and repair with bioinductive patch augmentation.

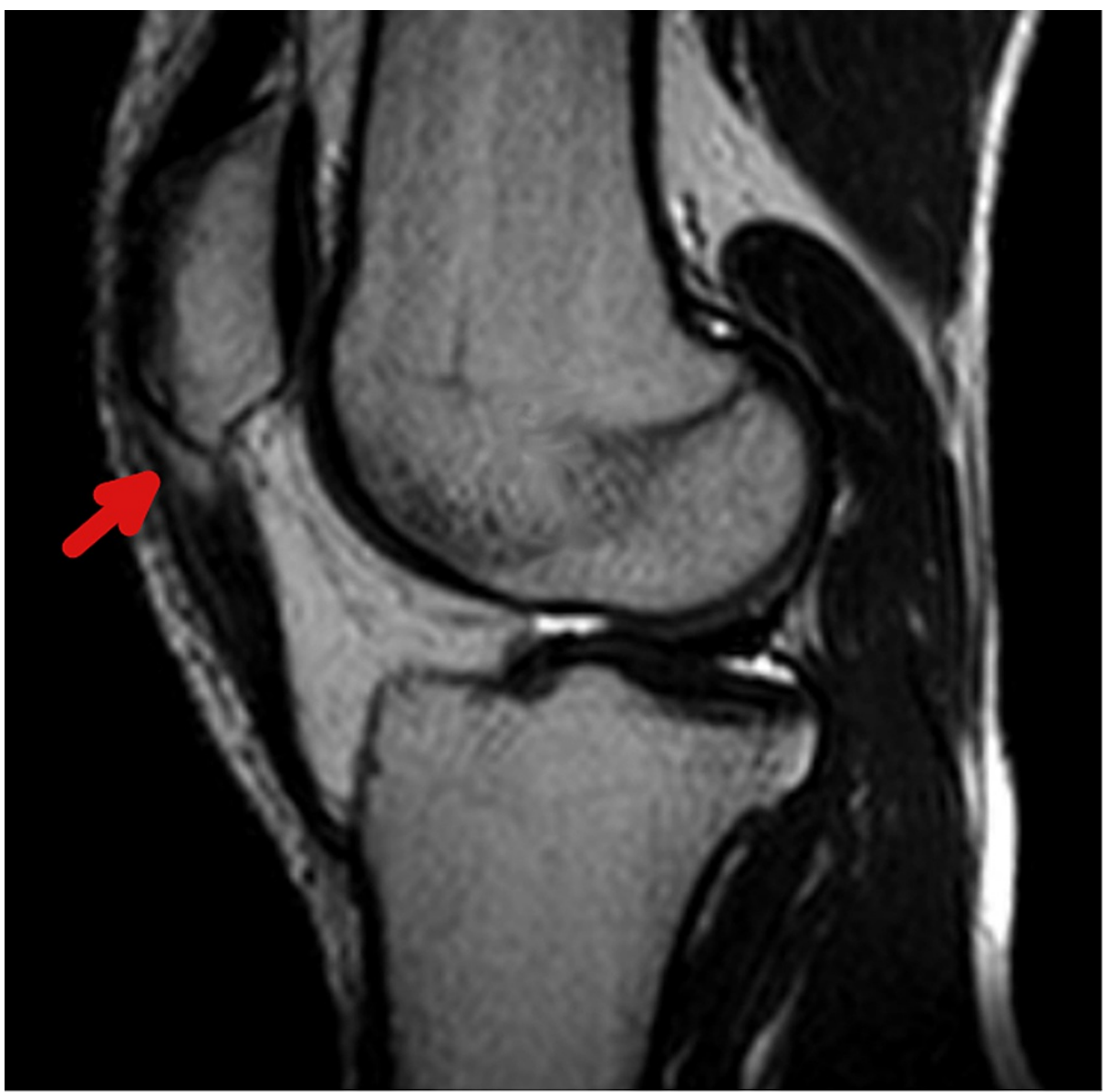

FIGURE 1: Sagittal T2-weighted MRI of the right knee of the first patient

The nidus of tendinopathy is plainly visible just distal to the inferior patellar pole (arrow)

MRI: magnetic resonance imaging

Surgery was performed with a thigh tourniquet through a $2.5-\mathrm{cm}$ longitudinal incision extending distally from the inferior pole of the patella (Figure $2 A$ ). The paratenon was divided sharply and preserved, and the tendon was split longitudinally in line with the fibers, exposing the underlying tendinopathic areas, which were sharply excised (Figure 2B). The inferior pole of the patella was decorticated to promote bleeding. A Regeneten bioinductive patch was laid over the tendon and secured with absorbable soft tissue staples (Figure 2C), followed by the closure of the paratenon (Figure $2 D$ ). 


\section{Cureus}
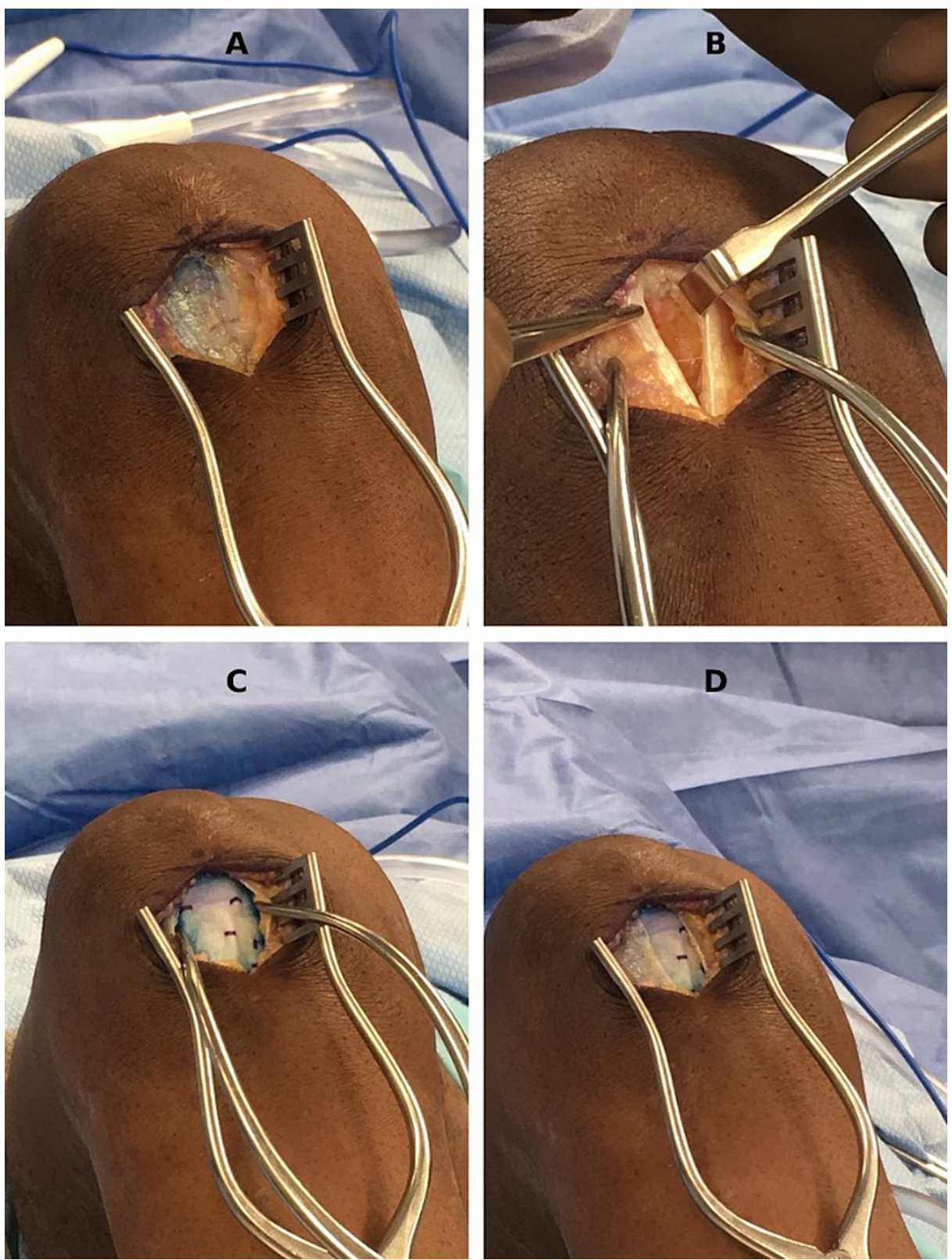

\section{FIGURE 2: Surgical procedure - patient 1}

A small longitudinal midline incision is extended distally from the inferior pole of the patella, and the paratenon layer is identified, sharply divided, and preserved, revealing the area of tendinopathy (A). The tendinopathic tissue is debrided, and the inferior pole of the patella is decorticated to promote the extravasation of marrow elements (B). An appropriately-sized (Smith \& Nephew) patch is applied and secured over the area with the included tissue staples (C), and the paratenon is closed over the top (D)

Postoperatively, the patient was placed in a hinged knee brace in full extension with 45 degrees allowable for passive motion, and he was immediately able to bear weight as far as tolerable. Therapy was initiated within the first week postoperatively, which consisted of quadriceps sets, heel slides, standing toe raises, ankle pumps, and hip abduction. At his first follow-up visit two weeks post-surgery, he reported no pain or any tenderness to palpation. At six weeks postoperatively, he still did not report any pain and was able to begin jogging. By his three-month follow-up, he had completed therapy and had been jogging up to two miles per day with intermittent sprint work. He returned to sport-specific training at six months postoperatively and was cleared to return without restrictions by eight months. By one year postoperatively, he had fully returned to all activities without any pain.

\section{Patient 2: chronic proximal hamstring tendinopathy}

A 40-year-old active female with over 20 years of posterior right hip pain presented for evaluation following an acute exacerbation due to running. Her symptoms were localized to the ischial tuberosity in the region of the hamstring origin. She denied any groin pain, lateral pain, or radicular symptoms. Her pain was 


\section{Cureus}

exacerbated by most activities and prevented her from exercising. She had previously failed eight months of formal physical therapy, three prolotherapy injections, and three platelet-rich plasma (PRP) injections. Examination revealed normal passive motion without groin pain, impingement signs, or trochanteric tenderness; marked tenderness over the proximal hamstring origin; and reproduction of symptoms with resisted prone knee flexion and plank test (Figure 3, representative image). An MRI of the right hip demonstrated proximal hamstring tendinosis with tearing of the deep fibers of semimembranosus origin (Figure 4). She agreed to undergo operative treatment.
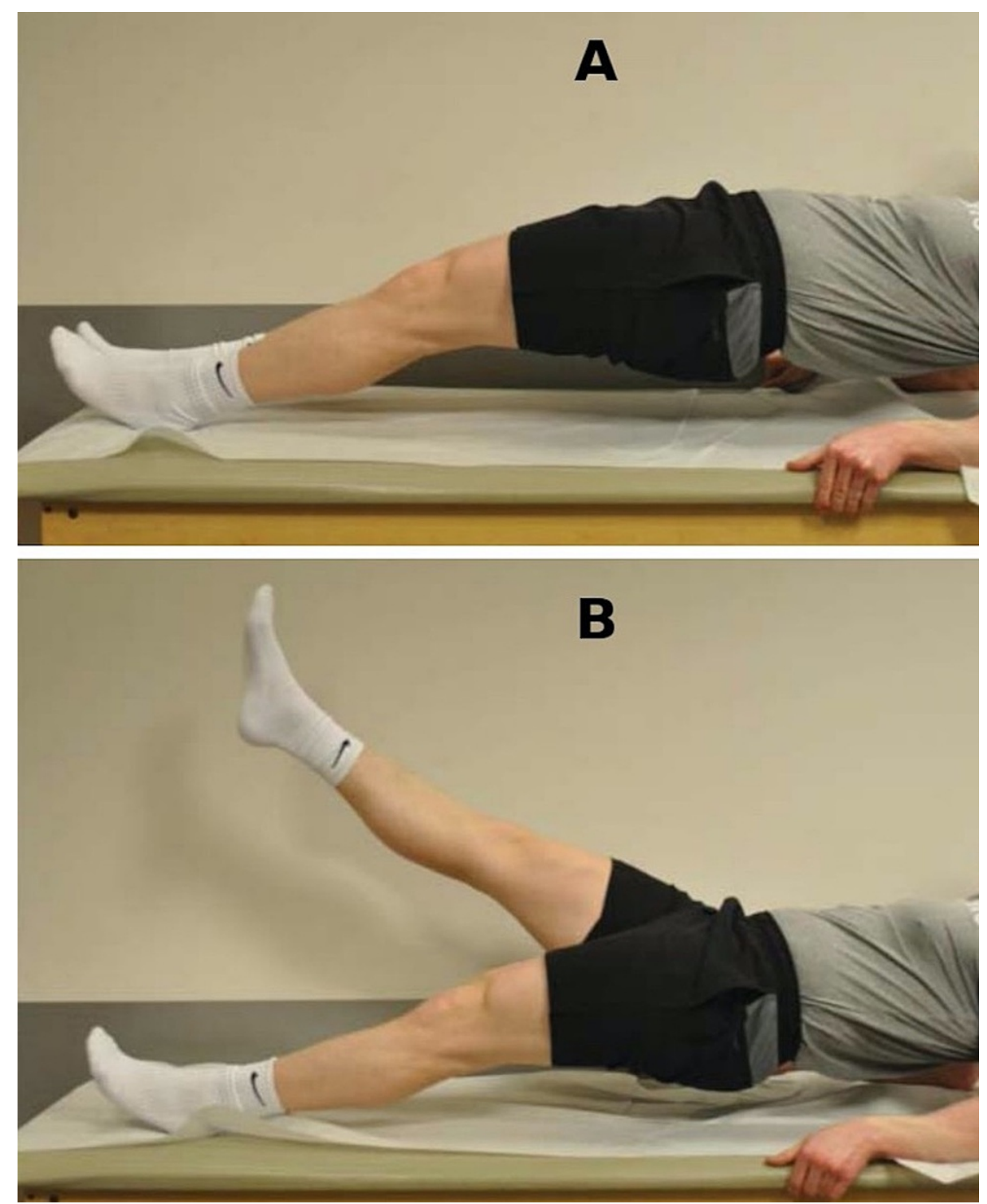

\section{FIGURE 3: Single-leg bridge or plank test for hamstring pathology}

The test is performed with the patient supine on the examination table. The patient is instructed to raise the pelvis off the table by extending both hips, supporting himself on his forearms and heels (A). The lower extremity of the unaffected side is then lifted off the table (B)

Adapted with permission from Arner et al., J Am Acad Orthop Surg., 2019[3] 


\section{Cureus}

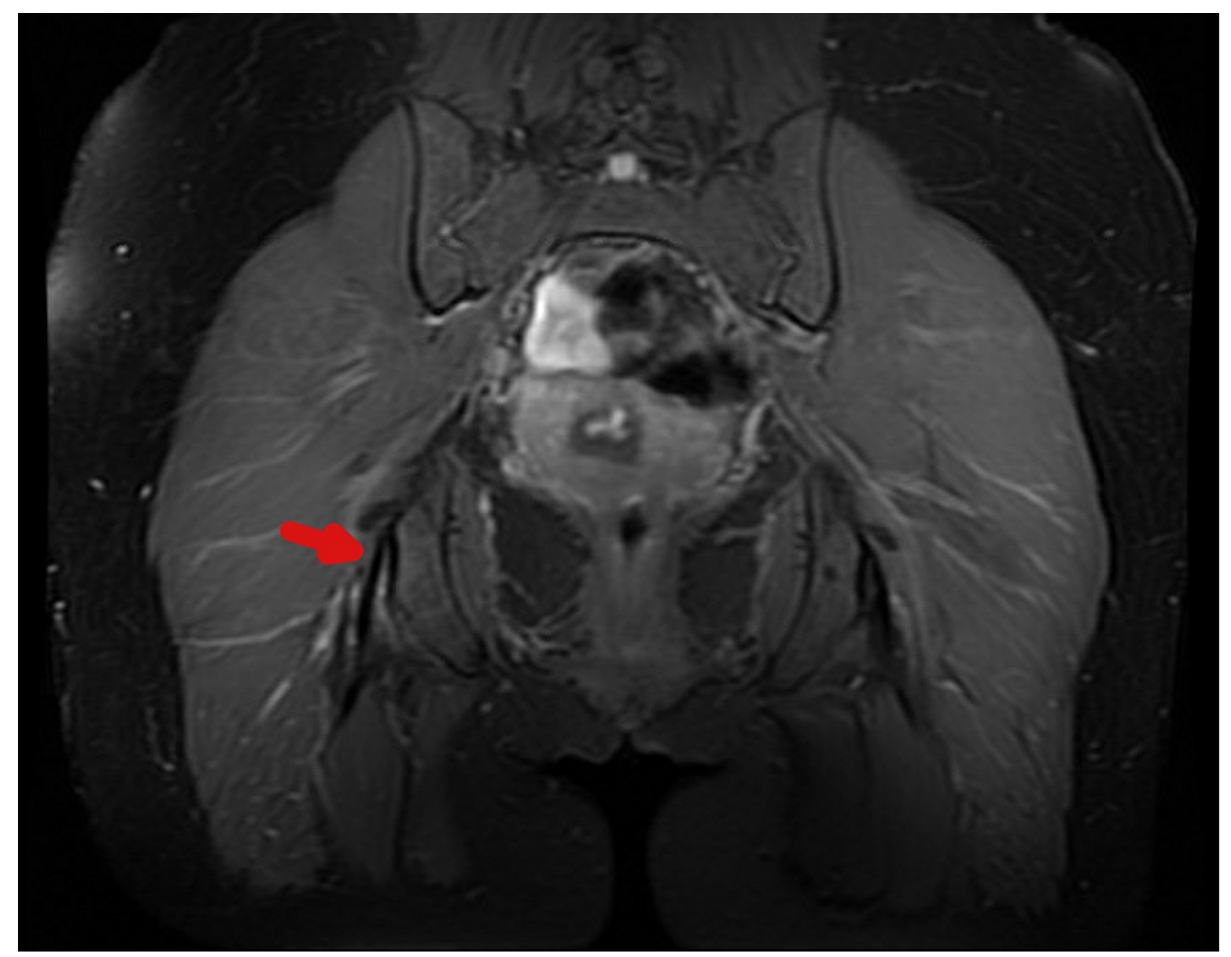

FIGURE 4: Coronal proton density (PD) fat-saturated (FS) MRI of bilateral hips at the level of the ischial tuberosities and lateral hamstring origins

On the right, a high-intensity signal at the origin is consistent with high-grade partial tearing and tendinopathy (arrow)

MRI: magnetic resonance imaging

A transverse incision was made within the right gluteal fold. With the gluteus major muscle retracted superiorly, the proximal hamstring fascia was identified and incised at the semimembranosus origin. The pathologic tissue was debrided. Several unicortical holes were drilled into the ischium with a 0.045 -inch Kirschner wire to allow extravasation of marrow contents (Figure $5 \mathrm{~A}$ ), and a Regeneten bioinductive patch was placed over the proximal hamstring origin (Figure $5 B$ ) and secured to the proximal tendon with the absorbable soft tissue staples. The area was then irrigated and closed. 


\section{Cureus}
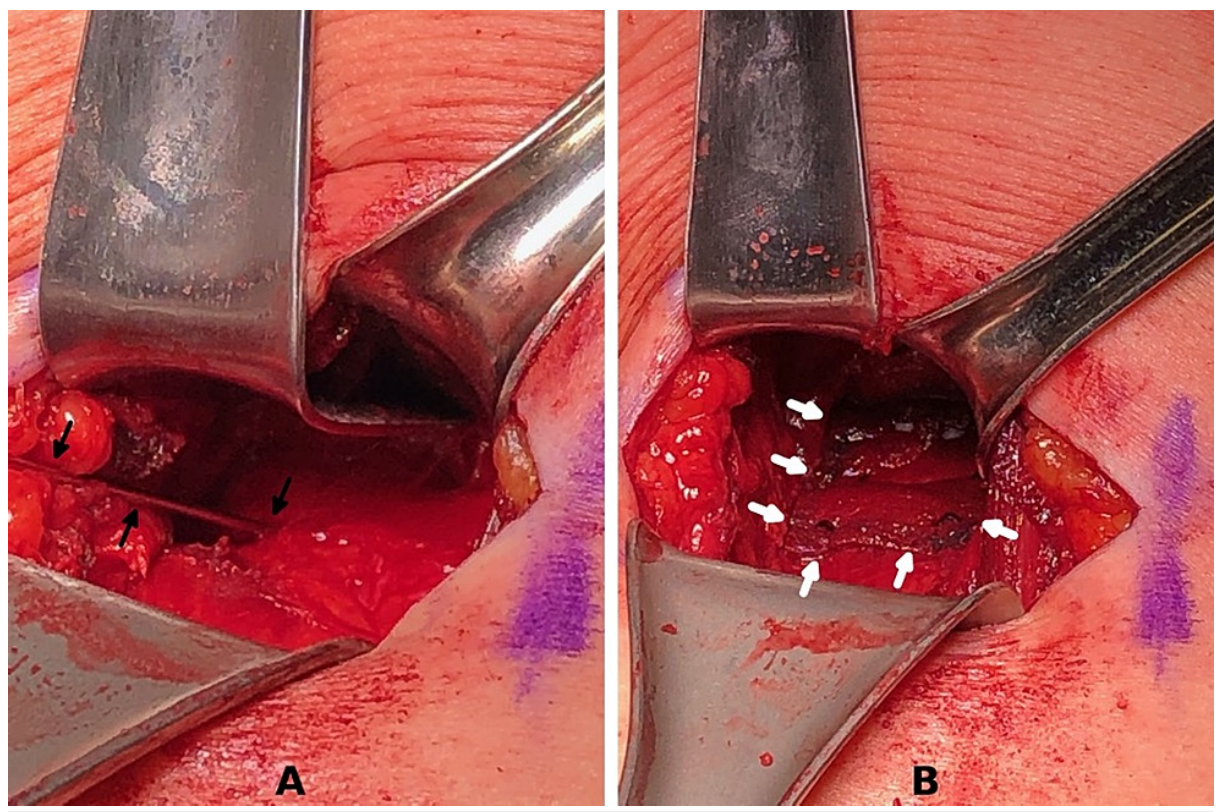

FIGURE 5: Surgical procedure - patient 2

The hamstring origin is exposed through a small transverse incision in the gluteal fold, retracting the inferior border of the gluteus maximus muscle superiorly. Adhesions and pathologic tissue is identified and debrided. The ischium is drilled with a Kirschner wire (A, black arrows) to promote the extravasation of marrow elements. A Regeneten bioinductive patch is then applied to the site and secured with the included tissue staples (B)

Postoperatively, the patient was placed into a hinged knee brace locked at 45 degrees for two weeks to protect the repair but was otherwise allowed to bear weight. Therapy was initiated during the first week postoperatively, consisting of ankle pumps and quadriceps sets. The brace was discontinued at the two-week follow-up visit with progressive motion and weight-bearing allowed. At her six-week follow-up, her pain was found to be improving, and she could ambulate without crutches. By nine weeks postoperatively, she was able to perform activities pain-free, which she had not been previously able to do, including the plank test. By 3.5 months postoperatively, she had returned to running and swimming and only experienced pain with prolonged sitting. By five months, she was running up to 3.5 miles three times a week, and her sitting pain had completely resolved. She continued swimming and running pain-free without recurrence with gradual improvement in her pace through her one-year follow-up period.

\section{Discussion}

Traditional surgical options for refractory chronic tendinopathies involve debridement of the involved tendon or peritendinous tissue with osseous drilling or decortication at attachment sites for marrow stimulation, possibly followed by formal repair (Tables 1, 2) [17-21]. However, the recovery period is often prolonged and complicated [22-24], which may be partially due to the fact that subsequent healing must occur under adverse conditions, the same that had contributed to the development of tendinopathy in the first place.

Bioaugmentation may help overcome local tissue deficiencies by promoting an increase of favorable growth factors and cytokines at the repair site [8]. To our knowledge, only one case of patellar tendon repair augmentation with a bioinductive implant has been reported in the literature, by McMillan et al. [12]. The patient was a 37-year-old male, an active-duty Air Force member with a nine-month history of chronic patellar tendonitis that had failed conservative measures. The surgical treatment included debridement of a tendinopathic focus near the patellar origin, decortication of the inferior pole of the patella, and formal suture anchor repair. Unlike in our case, PRP was added to the repair site before placing a Regeneten patch. We elected not to perform a formal repair as our patient's defect was not full-thickness, and a substantial portion of the tendon remained in continuity with the patella. Likewise, we did not feel that the addition of PRP would offer further benefits beyond the placement of the bioinductive patch.

Postoperatively, McMillan et al. had their patient on crutches for four weeks with partial weight-bearing. Given that we did not perform a formal repair, we allowed our patient to immediately bear weight as far as tolerable. Similar to our rehabilitation protocol, physical therapy was initiated by McMillan et al. within the first week postoperatively with gradual progression to full activity at three months. Sports activities involving jumping were restricted until six months postoperatively, which is also the duration for which we restricted sport-specific training. By way of clinical comparison, the patient in McMillan et al.'s case 


\section{Cureus}

reported a decrease in Visual Analog Scale for pain from 7 to 2 at six months postoperatively, while our patient reported an absence of pain as early as two weeks postoperatively, at which time he also expressed feeling better than he had felt prior to the surgery. This difference in outcomes may be attributed to the differing extents of the procedures performed, and differences in postoperative protocols.

We are not aware of any reports in the literature about Regeneten augmentation for proximal hamstring repairs to date. These can be difficult injuries to manage [3,5,25]. On average, it takes up to six months for conservatively managed patients to fully recover, while in $20 \%$ of patients, symptoms persist and become refractory to nonsurgical modalities [26]. In a cohort of 25 patients with partial-thickness tears who were managed with nonoperative treatment, $40 \%$ of the patients eventually required surgical intervention due to refractory pain or limited function [27]. In a systematic review, $99 \%$ of patients $(\mathrm{n}=266)$ with surgically treated proximal hamstring tendinosis and partial tears were able to return to sports [5], though in some cases recovery was protracted, and some athletes experienced residual symptoms [28-30]. In the series reported by Bowman et al., athletes began "gentle sport-specific activities" at 12 weeks, with an unrestricted return to activity delayed till six months. By comparison, our patient returned to running and swimming by three months postoperatively and was exercising at a higher-than-preinjury level by eight months.

\begin{tabular}{|c|c|c|c|c|c|c|c|c|c|c|}
\hline \multirow{2}{*}{ Lead author } & \multirow{2}{*}{ Year } & \multirow{2}{*}{ No.* } & \multicolumn{4}{|c|}{ Patient characteristics } & \multirow[t]{2}{*}{ Treatment } & \multirow[t]{2}{*}{ Outcomes } & \multicolumn{2}{|c|}{ Return-to-play } \\
\hline & & & $\begin{array}{l}\text { Age, } \\
\text { years }^{\dagger}\end{array}$ & Sex & Level(s) & Sport(s) & & & $\begin{array}{l}\text { No. } \\
(\%)^{\S}\end{array}$ & $\begin{array}{l}\text { Time } \\
\text { months }\end{array}$ \\
\hline Ferretti [31] & 2002 & $33 / 27$ & $\begin{array}{l}26.9 \\
(18- \\
31)\end{array}$ & $\begin{array}{l}24 \\
\mathrm{M}, \\
3 \mathrm{~F}\end{array}$ & $\mathrm{C} / \mathrm{P}$ & $\begin{array}{l}\text { Basketball, } \\
\text { dance, } \\
\text { football, } \\
\text { skiing, } \\
\text { tennis, } \\
\text { volleyball }\end{array}$ & $\begin{array}{l}\text { debridement, } \\
\text { IPP excision } \\
\text { and drilling }\end{array}$ & 23 excellent, 5 good, 1 fair, 4 poor $\|$ & $18(82)$ & 6 \\
\hline Pascarella [32] & 2011 & $73 / 64$ & $\begin{array}{l}24.6 \\
(16- \\
35)\end{array}$ & $\begin{array}{l}40 \\
M \\
24 \\
F\end{array}$ & $\mathrm{R} / \mathrm{P}$ & $\begin{array}{l}\text { Basketball, } \\
\text { running, } \\
\text { soccer, } \\
\text { tennis, } \\
\text { volleyball }\end{array}$ & $\begin{array}{l}\text { Arthroscopic } \\
\text { debridement } \\
\text { and IPP } \\
\text { excision }\end{array}$ & $\begin{array}{l}\text { Lysholm scores }{ }^{\dagger}: 1 \text { year: } 86.4(-), 3 \text { years: } 86.4 \\
(-) \text {; IKDC scores }{ }^{\dagger}: 1 \text { year: } 94.7(-), 3 \text { years: } 95.5 \\
(-)\end{array}$ & $\begin{array}{l}19 \\
(70.4)^{\pi}\end{array}$ & 5 \\
\hline Shelbourne [33] & 2006 & 22/16 & $\begin{array}{l}19.7 \\
(16- \\
25)\end{array}$ & $\begin{array}{l}10 \\
\mathrm{M} \\
6 \mathrm{~F}\end{array}$ & $\mathrm{C} / \mathrm{P}$ & $\begin{array}{l}\text { Basketball, } \\
\text { football, } \\
\text { volleyball, } \\
\text { track/field }\end{array}$ & $\begin{array}{l}\text { Open } \\
\text { debridement } \\
\text { and IPP } \\
\text { decortication }\end{array}$ & $\begin{array}{l}11 \text { excellent (return to preinjury level of activity } \\
\text { without pain), } 3 \text { good (return to preinjury level } \\
\text { of activity but with mild to moderate pain), } 2 \text { fair } \\
\text { (improvement in symptoms but unable to return } \\
\text { to preinjury level of sport, or moderate pain) }\end{array}$ & $\begin{array}{l}14 \\
(87.5)\end{array}$ & 8 \\
\hline $\begin{array}{l}\text { TABLE 1: P } \\
{ }^{\star} \text { Tendons/patien } \\
\text { rating scheme } \mathrm{n}\end{array}$ & $\begin{array}{l}\text { ts. 'Ave } \\
\text { ot spec }\end{array}$ & $\begin{array}{l}\text { rage ( } r \\
\text { ified. } 9 c\end{array}$ & $\begin{array}{l}\text { ange). }{ }^{\S} \\
\text { Dut of } 27\end{array}$ & $\begin{array}{l}\text { O pre } \\
\text { profe }\end{array}$ & $\begin{array}{l}\text { vious leve } \\
\text { ssional a }\end{array}$ & $\begin{array}{l}\text { l. 'To sport } \\
\text { thletes }\end{array}$ & fic training & t not necessarily full competition) at previ & level. & asis for \\
\hline $\begin{array}{l}\text { C: competitive }(\mathrm{r} \\
\text { male; } \mathrm{P} \text { : profess }\end{array}$ & $\begin{array}{l}\text { high sch } \\
\text { ional; } \mathrm{R}\end{array}$ & nool, co & $\begin{array}{l}\text { olegiate } \\
\text { ational }\end{array}$ & $\mathrm{ro}$ & pic); & male; IK & rnational K & e Documentation Committee; IPP: inferior pa & atellar po & le; M: \\
\hline
\end{tabular}




\section{Cureus}

\begin{tabular}{|c|c|c|c|c|c|c|c|c|c|c|}
\hline \multirow{2}{*}{ Lead author } & \multirow{2}{*}{ Year } & \multirow{2}{*}{ No. ${ }^{\star}$} & \multicolumn{4}{|c|}{ Patient characteristics } & \multirow{2}{*}{ Treatment } & \multirow[t]{2}{*}{ Outcomes } & \multicolumn{2}{|c|}{ Return-to-play } \\
\hline & & & $\begin{array}{l}\text { Age, } \\
\text { years }{ }^{\dagger}\end{array}$ & Sex & Level(s) & Sport(s) & & & $\begin{array}{l}\text { No. } \\
(\%)^{\S}\end{array}$ & $\begin{array}{l}\text { Time }^{+} \text {, } \\
\text { months }\end{array}$ \\
\hline Benazzo [34] & 2013 & $17 / 17$ & $\begin{array}{l}26.6 \\
(20- \\
34)\end{array}$ & $\begin{array}{l}12 \\
\mathrm{M} \\
5 \mathrm{~F}\end{array}$ & $\mathrm{C} / \mathrm{P}$ & $\begin{array}{l}\text { Running, } \\
\text { soccer, } \\
\text { track/field }\end{array}$ & $\begin{array}{l}\text { Open debridement, } \\
\text { ischial drilling, sciatic } \\
\text { neurolysis }\end{array}$ & $\begin{array}{l}15 \text { excellent (asymptomatic, able to return to same level of sport), } \\
2 \text { good (able to return to same level of sport with pain during } \\
\text { intense efforts); Tegner scoret: } 7.8 \text { (7-10) }\end{array}$ & $\begin{array}{l}17 \\
(100)\end{array}$ & 4 \\
\hline Bowman [29] & 2013 & 17/14 & $\begin{array}{l}43.3 \\
(19- \\
64)\end{array}$ & $\begin{array}{l}3 \\
M, \\
14 \\
F\end{array}$ & $R / C / P$ & $\begin{array}{l}\text { Bodybuilding, } \\
\text { dance, field } \\
\text { hockey, } \\
\text { running, tennis, } \\
\text { track/field, } \\
\text { waterskiing }\end{array}$ & $\begin{array}{l}\text { Open debridement, } \\
\text { ischial } \\
\text { curettage/decortication, } \\
\text { formal suture anchor } \\
\text { repair }\end{array}$ & Marx scalell: $6.5 \pm 5.3$, LEFSll: $73.3 \pm 9.9$ & $\begin{array}{l}14 \\
(100)\end{array}$ & NR \\
\hline Lempainen [2] & 2009 & $103 / 90$ & $\begin{array}{l}34 \\
(16- \\
63)\end{array}$ & $\begin{array}{l}58 \\
\mathrm{M} \\
32 \\
\mathrm{~F}\end{array}$ & $\mathrm{R} / \mathrm{C} / \mathrm{P}$ & $\begin{array}{l}\text { Aerobics, } \\
\text { dance, running, } \\
\text { skiing, soccer, } \\
\text { tennis, } \\
\text { track/field }\end{array}$ & $\begin{array}{l}\text { Open proximal } \\
\text { semimembranosus } \\
\text { tenotomy at origin, } \\
\text { tenodesis to biceps } \\
\text { femoris, } \pm \text { sciatic } \\
\text { neurolysis }\end{array}$ & $\begin{array}{l}62 \text { excellent (asymptomatic, able to return to same level of sport), } \\
30 \text { good (able to return to same level of sport with occasional } \\
\text { minor symptoms during strenuous sports activity), } 5 \text { fair (unable to } \\
\text { return to previous level due to persistent symptoms), } 6 \text { poor } \\
\text { (unable to participate in sports with symptoms affecting ADL) }\end{array}$ & $\begin{array}{l}80 \\
(89)\end{array}$ & 5 \\
\hline
\end{tabular}

TABLE 2: Previously published reports on surgically treated chronic proximal hamstring tendinopathy

${ }^{\star}$ Tendons/patients. ${ }^{\dagger}$ Average (range). § To previous level. ${ }^{\dagger}$ To sport-specific training (but not necessarily full competition) at previous level. $\|$ Mean \pm standard deviation (SD)

ADL: activities of daily living; C: competitive (high school, collegiate, or Olympic); F: female; LEFS: Lower Extremity Functional Scale; M: male; NR: not reported; P: professional; R: recreational

\section{Conclusions}

Bioaugmentation may represent an effective strategy in the surgical treatment of chronic tendinopathies outside of the shoulder, with both of our patients being able to return to their pre-injury activity levels at an accelerated rate. Larger series with long-term follow-ups and subsequent prospective trials are required to better evaluate the clinical implications of this emerging technology.

\section{Additional Information \\ Disclosures}

Human subjects: Consent was obtained or waived by all participants in this study. Conflicts of interest: In compliance with the ICMJE uniform disclosure form, all authors declare the following: Payment/services info: All authors have declared that no financial support was received from any organization for the submitted work. Financial relationships: All authors have declared that they have no financial relationships at present or within the previous three years with any organizations that might have an interest in the submitted work. Other relationships: All authors have declared that there are no other relationships or activities that could appear to have influenced the submitted work.

\section{References}

1. Peers KH, Lysens RJ: Patellar tendinopathy in athletes: current diagnostic and therapeutic recommendations. Sports Med. 2005, 35:71-87. 10.2165/00007256-200535010-00006

2. Lempainen L, Sarimo J, Mattila K, Vaittinen S, Orava S: Proximal hamstring tendinopathy: results of surgical management and histopathologic findings. Am J Sports Med. 2009, 37:727-34. $10.1177 / 0363546508330129$

3. Arner JW, McClincy MP, Bradley JP: Hamstring injuries in athletes: evidence-based treatment. J Am Acad Orthop Surg. 2019, 27:868-77. 10.5435/JAAOS-D-18-00741

4. Brockmeyer M, Diehl N, Schmitt C, Kohn DM, Lorbach O: Results of surgical treatment of chronic patellar tendinosis (jumper's knee): a systematic review of the literature. Arthroscopy. 2015, 31:2424-9. 10.1016/j.arthro.2015.06.010

5. Startzman AN, Fowler O, Carreira D: Proximal hamstring tendinosis and partial ruptures. Orthopedics. 2017, 40:e574-82. 10.3928/01477447-20170208-05

6. Degen RM: Proximal hamstring injuries: management of tendinopathy and avulsion injuries . Curr Rev Musculoskelet Med. 2019, 12:138-46. 10.1007/s12178-019-09541-x 
7. Bahr R, Fossan B, Løken S, Engebretsen L: Surgical treatment compared with eccentric training for patellar tendinopathy (Jumper's Knee). A randomized, controlled trial. J Bone Joint Surg Am. 2006, 88:1689-98. 10.2106/JBJS.E.01181

8. Looney AM, Leider JD, Horn AR, Bodendorfer BM: Bioaugmentation in the surgical treatment of anterior cruciate ligament injuries: a review of current concepts and emerging techniques. SAGE Open Med. 2020, 8:2050312120921057. 10.1177/2050312120921057

9. Khambete H, Keservani RK, Kesharwani RK, Jain NP, Jain CP: Emerging trends of nanobiomaterials in hard tissue engineering. Nanobiomaterials in Hard Tissue Engineering. Grumezescu AM (ed): William Andrew, Oxford, UK; 2016. 1:63-101.

10. Van Kampen C, Arnoczky S, Parks P, Hackett E, Ruehlman D, Turner A, Schlegel T: Tissue-engineered augmentation of a rotator cuff tendon using a reconstituted collagen scaffold: a histological evaluation in sheep. Muscles Ligaments Tendons J. 2013, 3:229-35.

11. McIntyre LF, Bishai SK, Brown PB 3rd, Bushnell BD, Trenhaile SW: Patient-reported outcomes after use of a bioabsorbable collagen implant to treat partial and full-thickness rotator cuff tears. Arthroscopy. 2019, 35:2262-71. 10.1016/j.arthro.2019.02.019

12. Mc Millan S, Faoao DO, Ford E: Treatment of an insertional high grade partial patellar tendon tear utilizing a bio-inductive implant. Arch Bone Jt Surg. 2019, 7:203-8.

13. Kaplan DJ, Dold AP, Fralinger DJ, Meislin RJ: Endoscopic gluteus medius repair augmented with bioinductive implant. Arthrosc Tech. 2016, 5:e821-5. 10.1016/j.eats.2016.03.011

14. Gulledge CM, Makhni EC: Open gluteus medius and minimus repair with double-row technique and bioinductive implant augmentation. Arthrosc Tech. 2019, 8:e585-9. 10.1016/j.eats.2019.01.019

15. Gotoh M, Hamada K, Yamakawa H, Inoue A, Fukuda H: Increased substance P in subacromial bursa and shoulder pain in rotator cuff diseases. J Orthop Res. 1998, 16:618-21. 10.1002/jor.1100160515

16. Washburn R 3rd, Anderson TM, Tokish JM: Arthroscopic rotator cuff augmentation: surgical technique using bovine collagen bioinductive implant. Arthrosc Tech. 2017, 6:e297-301. 10.1016/j.eats.2016.10.008

17. Rodriguez-Merchan EC: The treatment of patellar tendinopathy . J Orthop Traumatol. 2013, 14:77-81. 10.1007/s10195-012-0220-0

18. Andres BM, Murrell GA: Treatment of tendinopathy: what works, what does not, and what is on the horizon . Clin Orthop Relat Res. 2008, 466:1539-54. 10.1007/s11999-008-0260-1

19. Popp JE, Yu JS, Kaeding CC: Recalcitrant patellar tendinitis. Magnetic resonance imaging, histologic evaluation, and surgical treatment. Am J Sports Med. 1997, 25:218-22. 10.1177/036354659702500214

20. Karlsson J, Kälebo P, Goksör LA, Thomée R, Swärd L: Partial rupture of the patellar ligament . Am J Sports Med. 1992, 20:390-5. 10.1177/036354659202000404

21. Raatikainen T, Karpakka J, Puranen J, Orava S: Operative treatment of partial rupture of the patellar ligament. A study of 138 cases. Int J Sports Med. 1994, 15:46-9. 10.1055/s-2007-1021019

22. Kettunen JA, Kvist M, Alanen E, Kujala UM: Long-term prognosis for jumper's knee in male athletes. A prospective follow-up study. Am J Sports Med. 2002, 30:689-92. 10.1177/03635465020300051001

23. Cook JL, Khan KM, Harcourt PR, Grant M, Young DA, Bonar SF: A cross sectional study of 100 athletes with jumper's knee managed conservatively and surgically. The Victorian Institute of Sport Tendon Study Group. Br J Sports Med. 1997, 31:332-6. 10.1136/bjsm.31.4.332

24. Gaida JE, Cook J: Treatment options for patellar tendinopathy: critical review . Curr Sports Med Rep. 2011, 10:255-70. 10.1249/JSR.0b013e31822d4016

25. Bodendorfer BM, Curley AJ, Kotler JA, Ryan JM, Jejurikar NS, Kumar A, Postma WF: Outcomes after operative and nonoperative treatment of proximal hamstring avulsions: a systematic review and metaanalysis. Am J Sports Med. 2018, 46:2798-80. 10.1177/0363546517732526

26. Zissen MH, Wallace G, Stevens KJ, Fredericson M, Beaulieu CF: High hamstring tendinopathy: MRI and ultrasound imaging and therapeutic efficacy of percutaneous corticosteroid injection. AJR Am J Roentgenol. 2010, 195:993-8. 10.2214/AJR.09.3674

27. Piposar JR, Vinod AV, Olsen JR, Lacerte E, Miller SL: High-Grade partial and retracted $(<2 \mathrm{~cm})$ proximal hamstring ruptures: nonsurgical treatment revisited. Orthop J Sports Med. 2017, 5:2325967117692507. $10.1177 / 2325967117692507$

28. Aldridge SE, Heilpern GN, Carmichael JR, Sprowson AP, Wood DG: Incomplete avulsion of the proximal insertion of the hamstring: outcome two years following surgical repair. J Bone Joint Surg Br. 2012, 94:6602. 10.1302/0301-620X.94B5.28043

29. Bowman KF Jr, Cohen SB, Bradley JP: Operative management of partial-thickness tears of the proximal hamstring muscles in athletes. Am J Sports Med. 2013, 41:1363-71. 10.1177/0363546513482717

30. Puranen J, Orava S: The hamstring syndrome. A new diagnosis of gluteal sciatic pain . Am J Sports Med. 1988, 16:517-21. 10.1177/036354658801600515

31. Ferretti A, Conteduca F, Camerucci E, Morelli F: Patellar tendinosis: a follow-up study of surgical treatment . J Bone Joint Surg Am. 2002, 84:2179-85.

32. Pascarella A, Alam M, Pascarella F, Latte C, Di Salvatore MG, Maffulli N: Arthroscopic management of chronic patellar tendinopathy. Am J Sports Med. 2011, 39:1975-83. 10.1177/0363546511410413

33. Shelbourne KD, Henne TD, Gray T: Recalcitrant patellar tendinosis in elite athletes: surgical treatment in conjunction with aggressive postoperative rehabilitation. Am J Sports Med. 2006, 34:1141-6. $10.1177 / 0363546505284239$

34. Benazzo F, Marullo M, Zanon G, Indino C, Pelillo F: Surgical management of chronic proximal hamstring tendinopathy in athletes: a 2 to 11 years of follow-up. J Orthop Traumatol. 2013, 14:83-9. 10.1007/s10195013-0226-2 